\title{
Konversi Tinggi Pasang Surut Di Perairan Cilacap Terhadap Energi Yang Dihasilkan
}

\author{
Gentur Handoyo, Agus A. D. Suryoputro dan Ibnu Pratikyo \\ Jurusan IImu Kelautan, Fakultas Perikanan dan Ilmu Kelautan, Universitas Diponegoro \\ JI. Prof. Soedarto, S.H, Tembalang Semarang 50275 \\ Email: gentur.handoyo@yahoo.com
}

\begin{abstract}
Abstrak
Pasang surut merupakan parameter yang penting dalam memperoleh besaran energi pasang surut yang berdasarkan nilai muka air pasang tertinggi dan surut terendah. Perairan Kabupaten Cilacap, propinsi Jawa Tengah merupakan perairan yang terletak di Samudera Hindia yang diduga terdapat potensi energi pasang surut yang tinggi. Selain itu faktor lokal yang mempengaruhi adalah bentuk morfologi pantai yang berbentuk alamiah dan diperairan pantai seperti teluk dan selat sempit serta kedalaman perairan. Tipe pasang surut dan nilai muka air pasang tertinggi dan muka air surut terendah diperoleh menggunakan Metode Admiralty. Hasil yang didapt tipe pasang surut di perairan Kabupaten Cilacap Campuran Condong ke Harian Ganda dengan nilai formzahl 0,3. Sedangkan nilai muka air pasang tertinggi sebesar 2,3m dan surut terendah sebesar $0,05 \mathrm{~m}$. Hasil simulasi untuk luasan kolam tunggal $1,1 \mathrm{~km}^{2}$ diperoleh energi pasang surut sebesar $61.161 \mathrm{kWh}$ selama kurun waktu satu tahun di perairan Kabupaten Cilacap, Propinsi Jawa Tengah. Maka dapat disimpulkan, bahwa pemanfaatan perencanaan kedepannya untuk memperoleh energi pasang surut yang maksimal sebagai sumber energi alternatif.
\end{abstract}

Kata kunci : Energi, Pasang Surut, Perairan Cilacap

\begin{abstract}
Tidal is an important parameter in obtaining tidal energy quantities are based on the face value of the highest high water level and the lowest low water level. Cilacap Regency waters, Central Java province is located in the waters of the Indian Ocean which is allegedly contained the high potential tidal energy. Tidal are caused by the influece of the force attraction of the moon and the sun. Besides that the local factors affecting is the shaped of morphology coastal which is natural-shaped and in coastal waters such as gulf, narrow strait and the waters depth. The type and tidal value of the highest high water level and the lowest low water level is obtained by using admiralty methods, the results obtained in the tidal type Cilacap Regency waters mixed tide prevailing semi diurnal is formhazl value 0,3 . While the face value of the highest high water level is $2,3 \mathrm{~m}$ and the lowest low water level is $0,05 \mathrm{~m}$. Simulation results for expressing a single pool of $1,1 \mathrm{~km}^{2}$ of tidal ebergy acquired $61.161 \mathrm{kWh}$ for one year in the waters of Cilacap Regency, Central Java province. Thus it can be inferred that the utilization of energy obtained can be refference in the future construction planning in the future to obtain the maximum tidal energy as a source alternative energy.
\end{abstract}

Keywords : Energy, Tidal, Waters of Cilacap

\section{PENDAHULUAN}

Kebutuhan energi yang terus meningkat yang disebabkan karena bertambahnya jumlah penduduk di Indonesia menyebabkan berkurangnya jumlah energi konvensional. Energi konvensional merupakan energi yang bersifat unrenewable dan apabila digunakan secara terus menerus akan habis (Dahuri, 2001). Penggunaan energi konvensional tidak hanya berdampak 
pada krisis berkurangnya energi tetapi juga bisa berdampak pada krisis lingkungan hidup, karena sifatnya yang tidak dapat diperbaharui (Kadir, 1995). Menurut Manuala (2008), pemanfaatan energi yang bersumber dari pasang surut adalah merupakan salah satu alternatif yang bisa dikembangkan.

Pasang surut merupakan salah satu gejala alam yang ada di laut, yaitu suatu gerakan vertikal dari seluruh partikel massa air laut dari permukaan sampai bagian terdalam dari dasar laut yang disebabkan oleh pengaruh dari gaya tarik menarik antara bumi dan benda - benda angkasa terutama matahari dan bulan (Wibisono, 2005).

Menurut Dahuri (2001), Perairan Indonesia mempunyai kisaran tinggi pasang surut yang berbeda - beda di suatu tempat dengan tempat yang lain. Perairan Tanjung Priok kisarannya sekitar 1 meter, di perairan Ambon sekitar 2 meter, Bagan Siapi - api sekitar 4 meter, sedangkan yang tertinggi ditemukan di Sungai Digul dan selat Ikuli Papua Bagian selatan dengan kisaran 7 meter sampai 8 meter.

Perairan Kabupate Cilacap merupakan salah satu perairan di Indonesia dan terletak di bagian selatan Pulau Jawa Provinsi Jawa Tengah, dimana perairannya juga terdapat kisaran pasang surut. Untuk mengetahui seberapa besar energi yang dihasilkan dari pasang surut maka penelitian ini dilakukan.

\section{MATERI DAN METODE}

Materi penelitian yang digunakan dalam penelitian ini terdiri dari data primer dan data sekunder. Data primer berupa data pengamatan pasang surut selama 15 hari bulan Oktober tahun 2014 menggunakan palem pasut dengan 2 titik lokasi yang berbeda di perairan Kabupaten Cilacap, yaitu PPSC (Pelabuhan Perairan Samudera Cilacap) dan Stasiun Pandu. Terletak pada 07 43'42,2" LU - 10901 '27,3" BT dan 07 44' 28,7" LU - 108 59'47,1" untuk pengolahan data pasang surut yang mendukung keakuratannya, parameter yang mendukung adalah pasang surut dan karakteristiknya. Penentuan titik lokasi menggunakan GPS (Global Positioning System) Garmin Oseanografi TNI AL, sebagai pengolahan verifikasi data peramalan dengan data pengamatan, peta bethimetri, peta rupaumi wilayah perairan Cilacap.

Metode yang digunakan dalam penelitian ini adalah metode deskriptif. Metode deskriptif merupakan suatu penelitian yang bermaksud mengadakan pemeriksaan dan pengukuranpengukuran terhadap gejala tertentu (Fathoni, 2006). Penelitian dilakukan dengan pengukuran data pasang surut untuk mengetahui nilai pasang tertinggi dan surut terendah dalam memperoleh potensi energi pasang surut, kemudian dilakukan verifikasi data lapangan dan data peralaman untuk mengetahui karakteristiknya dan analisisnya.

Metode pengamatan pasang surut dalam penelitian ini menggunakan Palem Pesut selama 15 hari pada bulan Oktober tahun 2014. Menurut Subakti (2012) analisa data secara umum dibagi atas beberapa bagian berdasarkan jenis data yang digunakan dalam perhitungan dan kajian data. Analisa data pasang surut dilakukan dengan menggunakan Metode Admiralty untuk memperoleh nilai konstanta harmonik pasang surut yang meliputi Amplitudo (A)CM, M2, S2, K1, O1, N2, K2, P1, M4, MS4, mengetahui tipe pasang surut berdasarkan nilai formhazl, MSL, HHWL, dan LLWL.

Metode Admiralty atau kuadrat terkecil yang dikembangkan oleh A.T. Doodson, sistematika pengolahan data pengamatan pasang surut dengan bantuan skema dan tabel - tabel pengali (Poerbandono dan Djuarsah, 2005).

\section{Tinggi Potensi Energi Pasang Surut}

Hasi dari perhitungan konstanta harmonik pasang surut, diperoleh nilia tinggi potensi energi pasang surut berdasarkan muka air tinggi tertinggi (HHWL) dan tinggi muka air rendah terendah (LLWL) dalam satuan meter. 


\section{Simulasi Energi Pasang Surat}

Potensi energi pasang surut di peroleh dengan menggunakan simulasi sistem kolam tunggal dan sistem daur ganda. Sistem kolam tunggal ini merupakan gabungan dari sistem daur tunggal pasang dan daur surat (Dandekar dan Sherma, 1991 dalam Tantrawati, 2007)

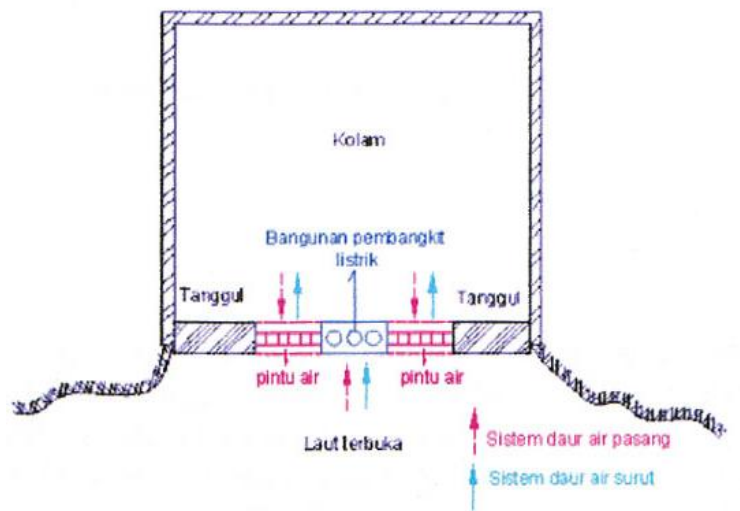

Gambar 1.Susunan kolam tunggal (Sumber: Dandekar dan Sherma, 1991 dalam Tantrawati, 2007)

Sistem ini sangat menguntungkan karena mampu membangkitkan tenaga listrik pada waktu pasang dan surut yang terdapat kira-kira 705 daur air pasang dalam satu tahun dengan memanfaatkan efisiensi turbin yang digunakan sebesar 0,75 $\mathrm{kg} / \mathrm{m}^{3}$. Perkiraan energi dihitung berdasarkan besarnya fungsi luas kolam dan beda tinggi pasang serta debit yang dihasilkan dengan persamaan perhitungan sebagai berikut:

$V=A x \Delta h$

$$
Q=\frac{V}{t}
$$

$P=\frac{0 x h y Q z y}{75}$

Selama kurun waktu satu tahun terdiri dari 365 hari dengan sistem daur ganda diketahui 705 daur pasang penuh maka energi yang dihasilkan selama satu tahun diperoleh berdasarkan perhitungan sebagai berikut:

$E_{(1 \text { tahun })}=\frac{2 x c x h p \times Q \times \gamma \times t \times 705 \times 0,736 \mathrm{kWh}}{75}$
Dimana :

$\checkmark$ : Volume aliran masuk kolam $\left(\mathrm{m}^{3}\right)$

A : Luas kolam ( $\left.\mathrm{m}^{2}\right)$

$\Delta h$ : Beda tinggi pasang dan surut $(\mathrm{m})$

Q : Debit air rata rata-rata ( $\mathrm{m}^{3} /$ detik)

$\dagger \quad$ : Lamanya pembangkit dalam satu kali operasi produksi (Detik)

$P$ : Besarnya tenaga (Daya) yang dihasilkan Kwh

$\mathrm{hp}$ : beda tinggi pasang dan surut ratarata

$y:$ : berat jenis air laut $1,025 \mathrm{~kg} / \mathrm{m}^{3}$

\section{Verifikasi Hasil Perhitungan Pasang Surut}

Verifikasi hasil dari perhitungan pasang surut yang dilakukan untuk membandingkan hasil pasang surut pengamatan dilapangan dengan pasang surut data sekunder. Besar kesalahan yang terjadi dihitung dengan mencari nilai MRE (Mean Relativ Error) (Riyanto, 2004 dalam Latifah, 2008). Perhitungan untuk mencari nilai tersebut adalah:

$M R E=\frac{|X-C|}{X} \times 100 \%$

Dimana:

MRE: Mean Relatif Error (Rata-rata kesalahan relatif)

C : Data hasil pengamatan lapangan

$X$ : Data peralaman

Kebenaran $(\%)=100-\frac{\text { Total MRE }}{\text { Jumlah data }}$

\section{HASIL DAN PEMBAHASAN}

\section{Pasang Surut}

Pengamatan pasang surut selama 15 hari di perairan Kabupaten Cilacapa menghasilkan nilai konstanta harmonik yaitu nilai amplitudi dan nilai kelambatan fase antara lain adalah S0, M2, S2, N2, K2, $\mathrm{K} 1, \mathrm{O} 1, \mathrm{Pl}$, M4, MS4, yang kemudian hasilnya akan dirata - ratakan selama kurun waktu satu tahun untuk mencari nilai Formzhal untuk mengetahui karakteristik pasang surut di perairan tersebut (Tabel 1) 

Tabel 1. Hasil Perhitungan Nilai Konstanta Harmonik Pasang Surut Menggunakan Metode Admiralty Selama 15 Hari Pada Bulan Oktober Tahun 2014

\begin{tabular}{cccccccccccc}
\hline Lokasi & & So & M2 & S2 & N2 & K2 & K1 & O1 & P1 & M4 & MS4 \\
\hline PPSC & $\mathrm{Acm}$ & 136 & 31 & 24 & 27 & 5 & 9 & 8 & 3 & 1 & 1 \\
& 9 & & 342 & 234 & 138 & 234 & 311 & 305 & 311 & 124 & 40 \\
Pandu & $\mathrm{Acm}$ & 130 & 31 & 23 & 27 & 5 & 8 & 9 & 3 & 1 & 1 \\
& $\mathrm{~g}$ & & 344 & 235 & 140 & 235 & 312 & 299 & 312 & 96 & 333 \\
\hline
\end{tabular}

Tabel 2. Hasil Perhitungan Nilai Konstanta Harmonik Pasang Surut Menggunakan Metode Admiralty Selama 29 Hari Pada Bulan Oktober Tahun 2014

\begin{tabular}{|c|c|c|c|c|c|c|c|c|c|c|}
\hline \multicolumn{11}{|c|}{ Hasil Terakhir } \\
\hline & So & $M 2$ & S2 & N2 & $\mathrm{K} 2$ & $\mathrm{~K} 1$ & 01 & $\mathrm{Pl}$ & M4 & MS4 \\
\hline Acm & 110 & 50 & 29 & 11 & 7 & 13 & 12 & 4 & 0 & 0 \\
\hline $\mathrm{g}$ & & 21 & 245 & 309 & 245 & 324 & 329 & 324 & 303 & 49 \\
\hline
\end{tabular}

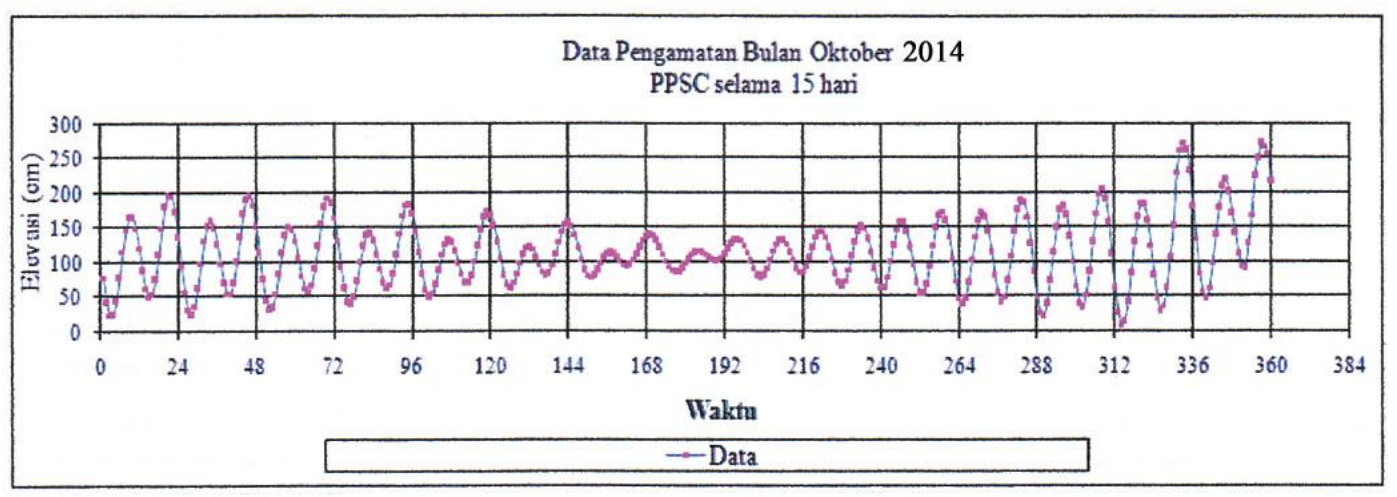

Gambar 2a.Grafik pengmatan pasang surut selama 15 hari di PPSC

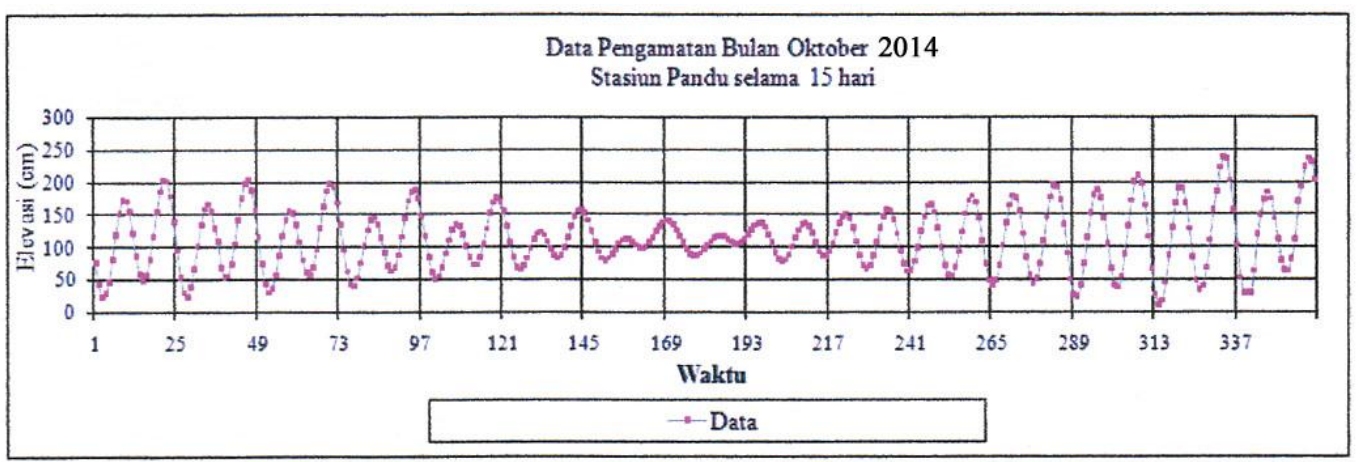

Gambar 2b.Grafik pengmatan pasang surut selama 15 hari di Stasiun Pandu

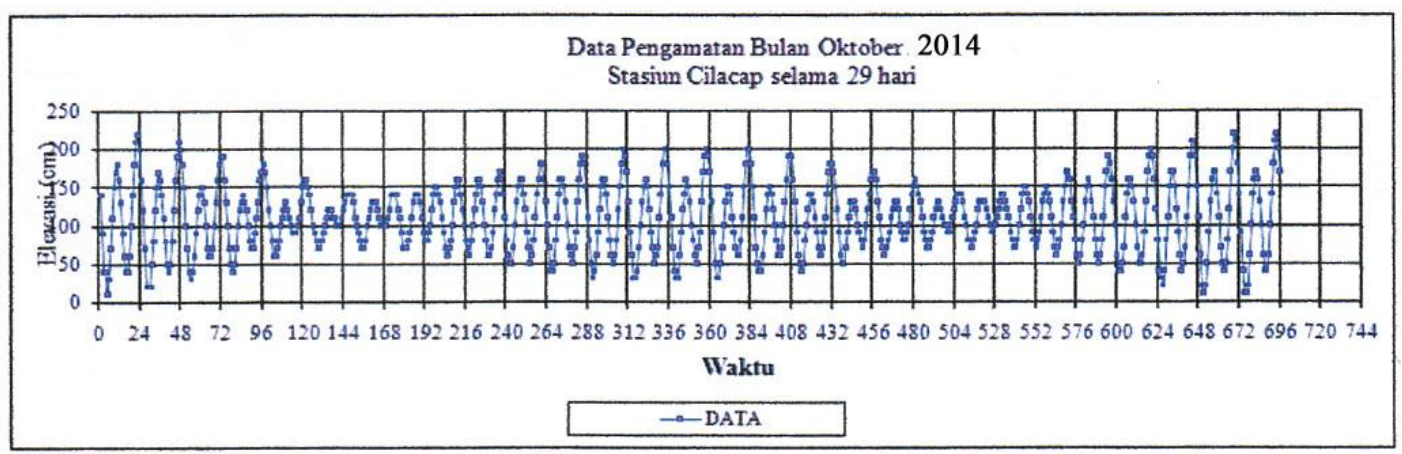

Gambar 2c. Grafik pengmatan pasang surut selama 15 hari di Perairan Kabupaten Cilacap 
Sedangkan hasil data pengamatan selama 29 hari dari peramalan pasang surut DISHIDROS TNI AL di Stasiun Cilacap pada bulan Oktober tahun 2014 menghasilkan nilai konstanta harmonik seperti pada tabel 2.

Grafik pasang surut yang diperolhe berdasarkan pengamatan selama 15 hari dan 29 hari di perairan Cilacap dapat dilihat pada gambar 2a, 2b dan 2c.

Gambar 2c merupakan hasil pengamatan pasang surut selama 29 hari berdasarkan BMKG yang bersumber dari DISHIDROS TNI AL pada bulan Oktober 2014. Hasil yang diperoleh nilai Formhazl berdasarkan perhitungan menggunakan metode Admiralty, dapat menentukan karakteristik atau tipe pasang surut dari perolehan nilai Formhazl. Pada titik stasiun pengamatan pasang surut didapat nilai formhazl 0,3. Pengelompokan tipe pasang surut yang terdapat di perairan Kabupaten Cilacap, Propinsi Jawa Tengah yaitu Pasang Surut Campuran Condong $\mathrm{Ke}$ Harian Ganda.

\section{Tinggi Pasang Surut}

Berdasarkan perhitungan analisa konstanta harmonik pasang surut diperoleh hasil tinggi pasang surut di Perairan Kabupaten Cilacap berdasarkan selisih antara HHWL (Highest High Water Level) dan LLWL (Lowest Low Water Level) selama 15 hari atau 29 hari.

Pada tabel 4a hasil tinggi pasang surut yang diperoleh selama 1 tahun pada tahun 2013 diperoleh rata-rata tingginya sebesar 2,30 di Perairan Cilacap. Tinggi terbesar diperoleh pada bulan Agustus sebesar 2,40 meter.

Pada tabel 4b hasil tinggi pasang surut yang diperoleh selama 2 tahun pada tahun 2013 - 2014 diperoleh rata-rata tingginya sebesar 2,29 di Perairan Cilacap. Tinggi terbesar diperoleh pada bulan Februari dan September sebesar 2,34 meter.

Berdasarkan hasil tabel $4 a$ dan $4 \mathrm{~b}$ diperoleh grafik tinggi pasang surut

Tabel 3. Hasil tinggi pasang surut pada 3 lokasi pengamatan di Perairan Kabupaten Cilacap

\begin{tabular}{rcccccc}
\hline No & Bulan & Tahun & HHWL $(\mathrm{m})$ & LLWL $(\mathrm{m})$ & $\mathrm{h}(\mathrm{m})$ & $\begin{array}{c}\text { Titik } \\
\text { Lokasi }\end{array}$ \\
\hline 1 & Oktober & 2011 & 2,2 & 0,6 & 1,6 & PPSC \\
2 & Oktober & 2011 & 2,1 & 0,5 & 1,6 & Pandu \\
3 & Oktober & 2011 & 2,3 & $-0,05$ & 2,35 & Cilacap \\
\hline
\end{tabular}

Tabel 4a. Hasil tinggi pasang surut tahun 2013 di Perairan Kabupaten Cilacap Propinsi Jawa Tengah

\begin{tabular}{cccccc}
\hline No & Bulan & Tahun & HHWL $(\mathrm{m})$ & LLWL $(\mathrm{m})$ & $\mathrm{h}(\mathrm{m})$ \\
\hline 1 & Januari & 2010 & 2,26 & $-0,05$ & 2,31 \\
2 & Februari & 2010 & 2,20 & $-0,07$ & 2,27 \\
3 & Maret & 2010 & 2,29 & $-0,09$ & 2,38 \\
4 & April & 2010 & 2,28 & $-0,01$ & 2,29 \\
5 & Mei & 2010 & 2,22 & $-0,02$ & 2,24 \\
6 & Juni & 2010 & 2,18 & $-0,05$ & 2,17 \\
7 & Juli & 2010 & 2,31 & $-0,06$ & 2,37 \\
8 & Agustus & 2010 & 2,30 & $-0,10$ & 2,40 \\
9 & September & 2010 & 2,27 & $-0,07$ & 2,34 \\
10 & Oktober & 2010 & 2,26 & $-0,06$ & 2,32 \\
11 & November & 2010 & 2,23 & $-0,02$ & 2,25 \\
12 & Desember & 2010 & 2,21 & 0,00 & 2,21 \\
\hline \multicolumn{7}{c}{ Rata-rata } & 2,25 & $-0,05$ & 2,30 \\
\hline
\end{tabular}


Tabel 4b. Hasil tinggi pasang surut tahun 2014 di Perairan Kabupaten Cilacap Propinsi Jawa Tengah

\begin{tabular}{cccccc}
\hline No & Bulan & Tahun & HHWL $(\mathrm{m})$ & LLWL $(\mathrm{m})$ & $\mathrm{h}(\mathrm{m})$ \\
\hline 1 & Januari & 2011 & 2,26 & $-0,05$ & 2,31 \\
2 & Februari & 2011 & 2,23 & $-0,11$ & 2,34 \\
3 & Maret & 2011 & 2,27 & $-0,07$ & 2,33 \\
4 & April & 2011 & 2,25 & $-0,06$ & 2,31 \\
5 & Mei & 2011 & 2,23 & $-0,03$ & 2,26 \\
6 & Juni & 2011 & 2,20 & 0,00 & 2,20 \\
7 & Juli & 2011 & 2,24 & $-0,04$ & 2,27 \\
8 & Agustus & 2011 & 2,26 & $-0,07$ & 2,33 \\
9 & September & 2011 & 2,27 & $-0,07$ & 2,34 \\
10 & Oktober & 2011 & 2,25 & $-0,05$ & 2,29 \\
11 & November & 2011 & 2,21 & $-0,02$ & 2,23 \\
12 & Desember & 2010 & 2,21 & $-0,01$ & 2,21 \\
\hline & Rata-rata & & 2,24 & $-0,05$ & 2,29 \\
\hline
\end{tabular}

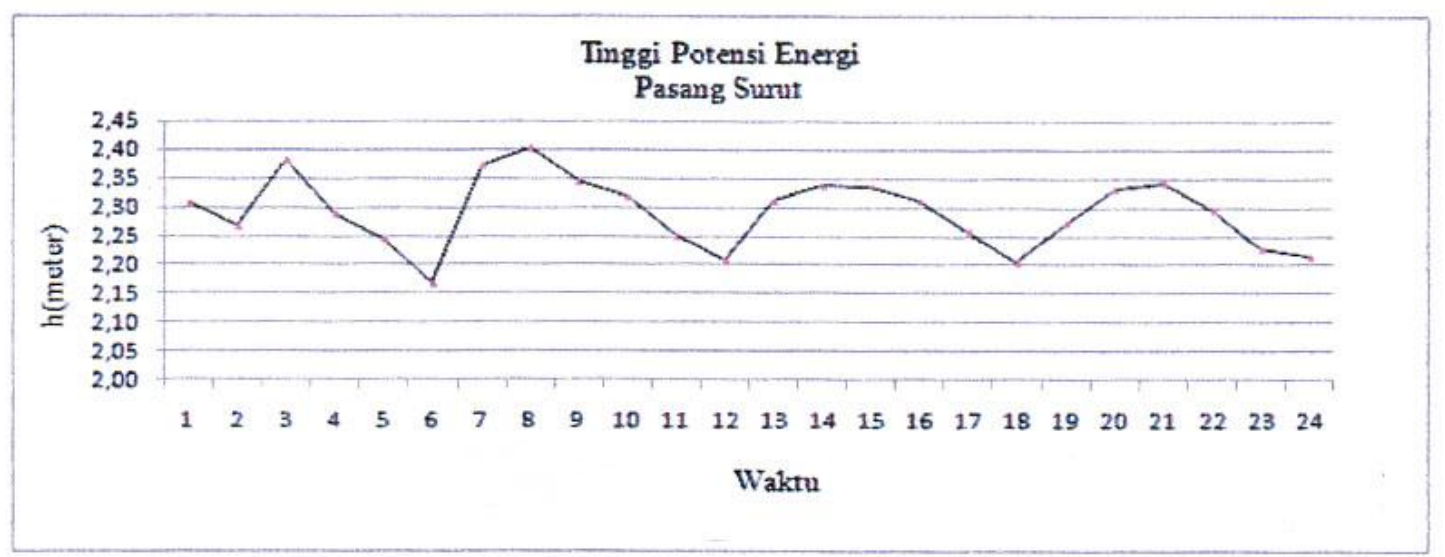

Gambar 3. Grafik Tinggi potensi energi pasang surut

selama kurun waktu 2 tahun di Perairan Kabupaten Cilacap. Tertinggi diperoleh pada bulan Agustus 2013 dan September 2014.

\section{Simulasi Energi Pasang Surut}

Hasil yang diperoleh berdasarkan simulasi untuk luasan kolam sebesar 1100 $\mathrm{m}^{2}$ didapat energi selama kurun waktu satu tahun sebesar 61.161 kWh (Tabel 5).

Pada Tabel 5 merupakan besar energi pasang surut tiap bulan selama kurun waktu satu tahun di perairan kabupaten Cilacap dengan besar energi $61.161 \mathrm{kWh}$.

Gambar 4 merupakan hasil perhitungan potensi energi pasang surut yang diperoleh berdasarkan simulasi luasan kolam sebesar $1,1 \mathrm{~km}^{2}$ pada tabel 5 . Potensi energi pasang surut dalam kurun waktu satu tahun pada 2014.

\section{Verifikasi Hasil Perhitungan Pasang Surut}

Hasil verifikasi dari data pengamatan pasang surut dengan data peralaman pasang surut perhitungannya sebagai berikut:

$M R E=\frac{|X-C|}{X} x 100 \%$

Dimana:

MRE = Mean Relatif Error (Rata-rata kesalahan relatif)

$\mathrm{C}=$ Data hasil pengamatan lapangan

$\mathrm{X}=$ Data peralaman 
Tabel 5. Energi yang dihasilkan selama kurun waktu satu tahun

\begin{tabular}{ccccc}
\hline $\begin{array}{c}\text { Luas } \\
\text { Kolam }\end{array}$ & $\Delta \mathrm{h}(\mathrm{m})$ & $\mathrm{V}$ & $\mathrm{Q}$ & $\mathrm{E}(\mathrm{KWh})$ \\
\hline 1.100 & 2,3101 & 2,26 & 0,7059 & 62.440 \\
1.100 & 2,3364 & 2,23 & 0,7139 & 63.869 \\
1.100 & 2,3349 & 2,27 & 0,7134 & 63.790 \\
1.100 & 2,3102 & 2,25 & 0,7059 & 62.449 \\
1.100 & 2,2578 & 2,23 & 0,6899 & 59.646 \\
1.100 & 2,2049 & 2,20 & 0,6737 & 56.885 \\
1.100 & 2,2721 & 2,24 & 0,6942 & 60.403 \\
1.100 & 2,3307 & 2,26 & 0,7122 & 63.562 \\
1.100 & 2,3421 & 2,27 & 0,7156 & 64.184 \\
1.100 & 2,2949 & 2,25 & 0,7012 & 61.625 \\
1.100 & 2,2276 & 2,21 & 0,6807 & 58.064 \\
1.100 & 2,2137 & 2,21 & 0,6764 & 57.341 \\
\hline Rata-rata & 2,2863 & 2514,921 & 0,6986 & 61.161 \\
\hline
\end{tabular}

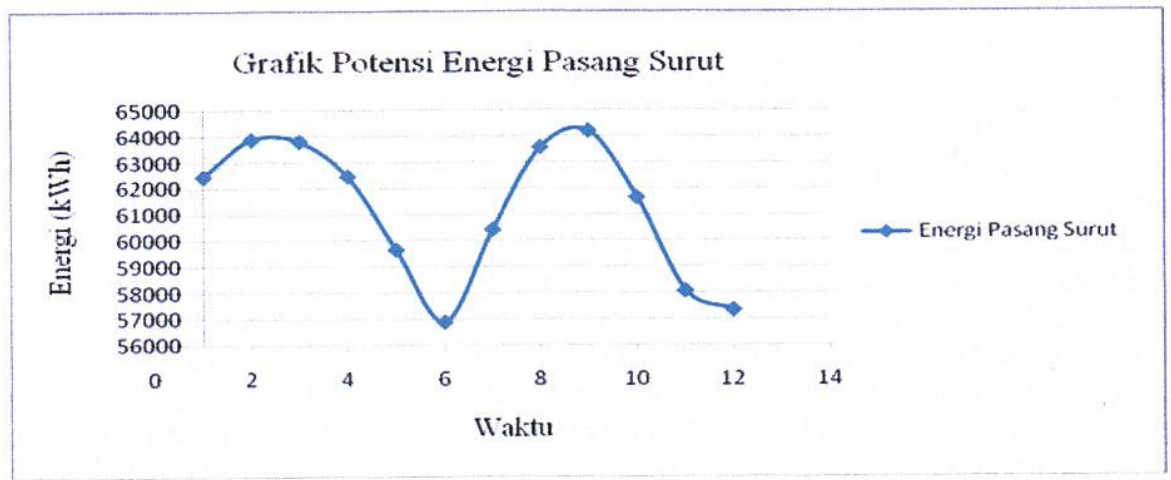

Gambar 4. Grafik potensi energi pasang surut tahun 2011
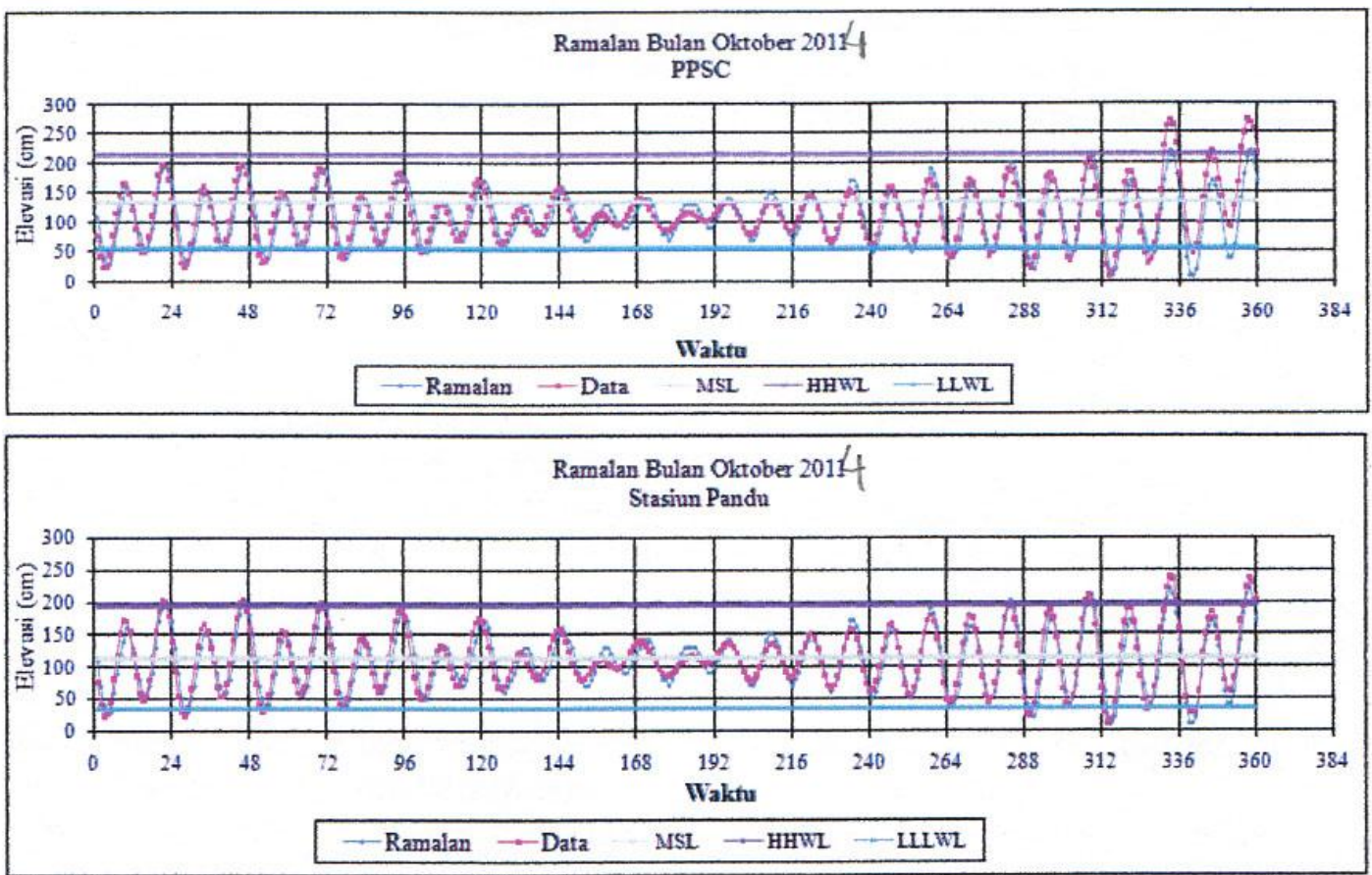

Gambar 11. Grafik verifikasi pasang surut bulan Oktober 2014, 2 lokasi di Perairan Kabupaten Cilacap 
Tinggi potensi energi pasang surut di perairan Kabupaten Cilacap yang diperoleh sangat tinggi berdasarkan pasang maksimum dan surut terendah. Menurut Manuaba (2008) energi yang diperoleh dari pembangkit pasang surut yaitu pada saat air laut pasang maupun saat air laut surut. Berdasarkan hasil yang diperoleh pada stasiun 1 tinggi pasang tertinggi lebih besar dibanding dengan stasiun 2 karena terdapat breakwater atau pemecah gelombang sedangkan pada stasiun 2 tidak ada penghalang langsung bertemu dengan laut, sehingga volume air pada waktu pasang di stasiun 1 sangat tinggi karena keluar masuk air lebih banyak dibandingkan dengan stasiun 2.

Tinggi potensi energi pasang surut berdasarkan hasil yang diperoleh dikarenakan pada saat bulan purnama atau bulan baru yang terjadi secara bergiliran setiap dua minggu sekali, ketika posisi bulan dan matahari terletak pada garis lurus dengan bumi sehingga terjadi pasang tertinggi selama 15 hari yaitu pada bulan baru dan bulan penuh. Menurut Setyawan (2008) perilaku pasang surut berebda-beda tergantung lokasi dan waktu di pantai selatan jawa.

Potensi energi pasang surut yang diperoleh di Perairan Kabupaten Cilacap berdasarkan simulasi pembuatan kolam pasang surut selama satu tahun dengan luasan kolam sebesar 1,1 km² memperoleh konversi energi selama satu tahun 61.161 kWh. Semakin besar luasan kolam yang dibentuk dan lamanya waktu yang diperoleh dalam operasi produksi maka semakin besar potensi energi yang dihasilkan sehingga pemanfaatan energi yang diketahui dapat dijadikan acuan dalam pembangunan perencanaan kedepannya untuk memperoleh energi pasang surut yang maksimal.

\section{KESIMPULAN}

Berdasarkan hasil penelitian ini dapat disimpulkan bahwa tipe pasang surut di Perairan Kabupaten Cilacap adalah campuran condong ke harian ganda dengan nilai formzahl $=0,3$. Analisa admiralty selama pengamatan 15 hari dan 29 hari diperoleh nilai muka air tinggi tertinggi (Highest High Water Level, HHWL) dan (Lowest Low Water Level, LLWL) diperairan Kabupaten Cilacap, untuk stasiun 1 (PPSC) nilai HHWL sebesar 2,2 m dan LLWL sebesar 0,6 $\mathrm{m}$, stasiun 2 (stasiun pandu) HHWL sebesar 2,1 $\mathrm{m}$ dan LLWL sebesar $0,5 \mathrm{~m}$ selama pengamatan 15 hari. Sedangkan hasil perhitungan HHWL dan LLWL untuk data peramalan yang bersumber dari DISHIDROS TNI - AL selama 29 hari diperoleh HHWL sebesar 2,3 dan LLWL sebesar $-0,05 \mathrm{~m}$ di perairan Kabupaten Cilacap.

Hasil tinggi potensi pasang surut di Perairan Kabupaten Cilacap berdasarkan perhitungan selisih antara HHWL dan LLWL sebesar 2,3 $\mathrm{m}$ dan potensi energi yang diperoleh berdasarkan simulasi dengan luasan $1,1 \mathrm{~km}^{2}$ sebesar $61.161 \mathrm{kWh}$ selama kurun waktu satu tahun pada tahun 2014.

\section{DAFTAR PUSTAKA}

Dahuri, Rokhim. Jacub Rias dan Sapta P.G. 2001. Pengelolaan Sumber Daya Wilayah Pesisir dan Lautan Secara Terpadu. Pradaya Paramita: Jakarta.

Dandekar, M.M dan Sharma, K.N.1991. Pembangkit Listrik Tenaga Air. Universitas Indonesia: Jakarta.

Fathoni, A. 2006. Metodologi Penelitian dan Teknik Penyusunan Skripsi. Rineka Cipta. Jakarta.

Kadir, A. 1995. Energi Sumber Daya, Inovasi, Tenaga Listrik dan Potensi Ekonomi Edisi Kedua. Universitas Indonesia. Jakarta.

Kadir, A. 2004. Pusat Listrik Tenaga Pasang Surut : Suatu Potensi Yang Cukup Besar dalam Teknologi dan Energi 06(03): 226 $-238$.

Latifah, N. 2010. Studi Hidrodinamika dan Kualitas Perairan di Pelabuhan Perikanan Pangembangan - Bali. Skripsi Sarjana Fakultas Perikanan dan Kelautan Universitas Diponegoro Semarang.

Manuaba, IBG dan Kadek. 2008. Potensi Energi Pasang Surut (Tidal Energy untuk Alternatif Pembangkit Tenaga Listrik di Bali. Bali, 15 (3): 338 - 349. 
Poerbandono dan Djunarsjah, E. 2005. Survei Hidrografi. Refika Aditama: Bandung.

Setyawan, A.D., Ari Susilowati dan Wiryanto. 2002. Habitat Reliks Vegetasi Mangrove di Pantai Selatan Jawa. FMIPA: UNS Surakarta, 03 (3): 242 - 256.

Subakti, H. 2012. Karakteristik Pasang Surut dan Pola Arus di Muara Sungai Musi Sumatera Selatan. FMIPA Universitas Sriwijaya, Sumatera Selatan, 15 (1): 35 39.
Sumotarto, U. 2003. Pemanfaatan Energi Pasang Surut. Jurnal Sains Indonesia, 05 (5): $85-93$.

Tantrawati, E. 2007. Potensi Pembangkit Listrik Tenaga Pasang Surut Sistem Daur Ganda dengan Kolam Tunggal. UII, Yogyakarta, 04(1): $64-76$.

Wulandari, D. 2002. Studi Potensi Energi Angin, Energi Gelombang dan Energi Pasang Surut Indonesia. Thesis Teknik Sipil Institus TeknikGeologi Bandung. 